\title{
ISU SOSIAL DALAM BENTUK INTERNET MEME MENJELANG PEMILIHAN PRESIDEN 2019 (Analisis Konten pada Meme Gambar dalam Instagram @memecomic.id)
}

\author{
Nova Rachmawati Puteri ${ }^{1}$, Adi Bayu Mahadian ${ }^{2}$ \\ ${ }^{1,2}$ Program Studi Ilmu Komunikasi, Fakultas Komunikasi dan Bisnis, Universitas Telkom \\ Jl. Telekomunikasi No.1 Terusan Buah Batu Bandung, INDONESIA \\ Email: ${ }^{1}$ nova.puteri@yahoo.co.id, ${ }^{2}$ adibayumahadian@telkomuniversity.ac.id
}

\begin{abstract}
ABSTRAK
Menjelang pemilihan presiden tahun 2019, masyarakat Indonesia menggunakan isu sosial dalam konteks perbincangan politik. Perbincangan tersebut terepresentasikan dalam akun Instagram @ memecomic.id, salah satu komunitas internet memes terbesar di Indonesia. Untuk mempelajari penggunaan internet memes yang memperbincangkan isu sosial menjelang Pemilihan Presiden 2019, maka dilakukan penelitian menggunakan metode penelitian kualitatif analisis isi deskriptif. Penelitian ini dilandasi oleh konsep internet memes dikemukakan oleh Shifman (2014:7), yaitu form, content, dan stance. Hasil penelitian ini menunjukkan bahwa Internet memes menjadi sarana menyampaikan pendapat dan kritik terhadap praktik politik para politikus di Indonesia, dengan memperbincangkan masalah sosial yang populer. Penyampaian pendapat dipresentasikan dalam bentuk meme gambar, yang berisi sindiran atau satir. Sebagian konten-konten yang dijadikan internet meme gambar dibuat secara serius atau tidak menggunakan humor dan secara tidak serius. Sebagian lainnya dibuat dengan menambahkan unsur humor atau lelucon pada setiap cerita yang terdapat pada meme-meme tersebut.
\end{abstract}

Kata kunci: Internet memes; isu sosial; pemilihan preseiden 2019.

\begin{abstract}
Towards the Presidential Election, Indonesian people use social issues in the context of political discourses. The discourses were represented on the Instagram account @memecomic.id, one of the largest internet memes creator communities in Indonesia. This study is to examines the use of the internet memes that discuss social issues toward the Presidential Election. It was conducted by using descriptive qualitative research methods. This research is based on the concept of internet memes that proposed by Shifman (2014). The results of the study is that the Internet has become a means of expressing opinions and criticisms of the political practices of politicians in Indonesia, by discoursing popular social problems. Its was represented in the form of visual memes, which contain insinuation or satire. Some are visual memes, with a serious content, and another are jokes or humor memes.
\end{abstract}

Keywords: Meme; social issues; 2019 presidental election.

\section{PENDAHULUAN}

Masalah dan isu sosial semakin intensif diperbincangkan menjelang pemilihan Presiden (Harahap, 2018). Seringkali isu sosial tersebut diperbincangkan dalam konteks perbincangan politik, bahkan dijadikan alat untuk menyerang lawan politik. Menjelang pemilihan Presiden 2019, media arus utama banyak memberitakan masalah sosial seperti diskriminasi etnis dan ras, berita palsu, dan ujaran kebencian yang memicu perpecahan dan kerusuhan masyarakat Indonesia (Asmoro, 2018; Jegho, 2018). Perbincangan tersebut berpotensi meluas dan semakin intensif diperbincangkan melalui media sosial. Salah satu bentuk perbincangan yang popular dilakukan masyarakat melalui media sosial adalah dalam bentuk internet memes, dan menjadikan internet memes sebagai salah satu bentuk perbincangan isu sosial yang popular saat ini.
Internet memes adalah konten digital yang berisi karakter umum, yang dibuat, diimitasi, dan disirkulasikan melalui internet oleh banyak orang atas dasar kesadaran bersama (Shifman, 2014). Internet memes dapat berbentuk visual, audial, teks, hyperlink atau kombinasi di antaranya. Sebuah internet memes lazimnya berisi wacana yang memperbincangkan isu tertentu (Campbell, Arredondo, Dundas, \& Wolf, 2018; Silvestri, 2016). Wacana tersebut dapat berevolusi melalui tindak imitasi dan replikasi yang dilakukan oleh banyak orang (Seiffert-Brockmann, Diehl, \& Dobusch, 2018). Hanya meme yang sesuai dengan sosial budaya masyarakat saja yang dapat bertahan, apabila tidak sesuai yang lainnya akan punah (Shifman, 2014).

Internet meme telah menjadi bagian penting demokrasi Indonesia, yang menjadi sarana ekspresi sikap dan pikiran masyarakat tentang berbagai 
peristiwa yang terjadi sehingga internet meme menjadi salah satu sarana representasi realitas tertentu masyarakat Indonesia (Dewi, Abdullah, Maryani, \& Suganda, 2017; Juditha, 2015), termasuk realitas sosial yang terjadi di tengah masyarakat Indonesia. Realitas tersebut terepresentasikan dalam memememe yang disirkulasikan dalam komunitas Meme Comic Indonesia. Sebuah salah satu komunitas online meme creator terbesar di Indonesia, yang membuat dan menyebarkan internet meme melalui berbagai flatform dalam jaringan internet (Arifianti, 2015). Salah satu flatform yang digunakan untuk mensirkulasikan internet meme yang populer adalah Instagram. Dengan nama akun @memecomic.id, komunitas ini membuat, dan menyebarkan berbagai konten dalam bentuk internet meme.

Konten yang dibuat dan disebarkan oleh komunitas ini beragam, mulai dari lelucon remaja, masalah sosial, hingga ekspresi politik. Namun menjelang pemilihan presiden, internet meme yang mewacanakan berbagai isu, cenderung dikaitkan dengan isu politik. Beberapa pembuat internet meme ditangkap polisi karena dianggap menghina Presiden dan menyebarkan kebencian (Aliansyah, 2017; Faisal, 2018; Firmansyah, 2018; Halim, 2018). Internet meme yang berisi isu sosial menjadi penting. Karena berpotensi untuk menjadi alat politik, dan menyerang lawan politik. Substansi isu-isu sosial dalam meme cenderung terpinggirkan, dan di rekontekstualisasikan kedalam isu politik. Karena itu, penelitian ini berupaya untuk memahami bagaiman isu sosial tetap diperbincangkan menjelang pemilihan Presiden 2019, waktu dimana wacana politik mendominasi perbincangan dimuka umum.

Berdasarkan uraian di atas, adapun identifikasi masalah dalam penelitian ini, yaitu; (a) apa saja jenis isu sosial yang menjadi bahan perbincangan menjelang pemilihan presiden 2019 dalam bentuk internet meme pada akun instagram @ memecomic.id, dan (b) bagaimana isi konten isu sosial menjelang pemilihan presiden 2019 yang diperbincangkan dalam bentuk internet meme pada akun instagram @memecomic.id. Selain itu penelitian ini menggunakan metode penelitian kualitatif analisis isi deskriptif berdasarkan elemen meme yang dikemukakan oleh Shifman (2014, p. 7) yaitu form (bentuk), content (isi), dan stance (sikap).

\section{KAJIAN TEORITIS}

\subsection{Kajian Teori Meme}

Istilah Meme pertama kali diciptakan oleh Richard Dawkins dalam buku The Selfish Gene pada tahun
1976, ia menjelaskan bahwa meme merupakan gambaran unit-unit budaya kecil yang menyebar sama halnya seperti virus (Shifman, 2014). Menurut Shifman, meme didefinisikan sebagai "a group of digital items sharing common characteristics of content, form, and/or stance; that were created with awareness of each other; and were circulated, imitated, and/or transformed via the Internet by many users".. Hanya meme yang sesuai dengan sosial budaya masyarakat saja yang dapat bertahan, apabila tidak sesuai yang lainnya akan punah (Shifman, 2014).

Seiring dengan perkembangan zaman, kini meme tidak hanya replikasi dari sebuah ide saja, tetapi kini meme dikembangkan menjadi sebuah replikasi ide yang dikemas berupa gambar atau video lucu disertai tulisan yang tersebar melalui internet. Saat ini internet meme memiliki peranan yang penting di dunia komunikasi menggunakan internet. Ciri khas dari internet meme sendiri adalah gambarnya yang bersifat sederhana dan pesan yang mudah di mengerti oleh pembacanya. Bentuk replikasi dari internet meme adalah ketika sebuah fenomena atau kejadian yang sedang terjadi atau sudah berlalu, kemudian seseorang mengeditnya sesuai dengan pesan yang ingin disampaikan, dan kemudian hasil tersebut diunggah ke berbagai media yang nnti nya disebarluaskan kembali oleh orang-orang.

Jadi, dapat disimpulkan bahwa internet meme adalah sebuah replikasi ide yang dibuat dalam bentuk gambar, video, atau teks yang memiliki fungsi sebagai sebuah hiburan, pertukaran ide atau pikiran, dan informasi yang dapat digunakan oleh semua kalangan. Dalam sebuah meme juga terdapat unsurunsur atau konten yang digunakan sebagai kritik, maupun saran terhadap suatu keadaan. Kontenkonten tersebut dapat berupa isu sosial, isu politik, humor dan lain-lain.

Menurut Shifman, meme didefinisikan memiliki elemen umum berupa:

1) Bentuk (Form)

Bentuk adalah wujud dari meme tersebut baik berupa audio, visual, maupun audio visual. Bentuk dalam sebuah meme dapat berupa gambar saja, maupun video saja, atau gambar maupun video yang dilengkapi sebuah teks atau tulisan yang menjelaskan mengenai meme tersebut.

2) Konten (Content)

Konten merupakan maksud dan arti dari sebuah teks, gambar, atau isi yang terdapat pada sebuah meme itu sendiri. 
3) Sikap (Stance)

Sikap dalam hal ini merupakan sikap bagi seseorang yang membuat dan menyebarkan meme tersebut.

\subsection{Kajian Teori Isu Sosial}

Isu sosial merupakan sarana mengungkapkan gagasan-gagasan yang baru mengenai kehidupan sehari-hari masyarakat. Isu sosial didefinisikan sebagai kontrol sosial dan menjadi salah satu bentuk komunikasi terhadap jalannya sebuah proses bermasyarakat atau sebuah sistem sosial (Nurgiyantoro, 2005, pp. 330-334). Dalam isu sosial terdapat pesan sosial yang digunakan untuk mengkritik tentang sebuah kondisi sosial yang sedang terjadi di masyarakat. Dalam kehidupan masyarakat, gejalagejala yang dikehendaki yang disebabkan oleh unsurunsur masyarakat yang tidak dapat berfungsi sebagai mestinya dapat dikatakan sebagai masalah-masalah sosial (Soekanto, 2007). Menurut Herabudin (2015), terdapat enam jenis isu sosial yang terkait dengan kehidupan sosial yang ada di masyarakat, yaitu:

\section{1) Kemiskinan}

Kemiskinan adalah keadaan dimana seseorang tidak mampu dalam memenuhi kebutuhan primer seperti makanan, pakaian, tempat tinggal, dan hartanya dianggap tidak mencukupi untuk memenuhi taraf kehidupan yang ada. Di kota metropolitan, seseorang yang dianggap miskin adalah seseorang yang tidak memiliki televisi, mobil, ataupun barang lainnya. Sehingga terjadi perubahan barang-barang sekunder kini dijadikan ukuran untuk keadaan sosial ekonomi seseorang (Soekanto, 2007).

Secara sosiologis, kemiskinan merupakan salah satu problem sosial yang paling serius dialami oleh negara-negara berkembang. secara umum, kajian tentang kemiskinan dapat ditinjau dari dua perspektif, yaitu perspektif kultural, dan structural (Herabudin, 2015).

2) Masalah Kenakalan Remaja atau Perilaku Menyimpang Remaja

Perilaku menyimpang (deviasi sosial) adalah semua bentuk perilaku yang tidak sesuai dengan norma-norma sosial yang ada. Jadi, perilaku menyimpang remaja adalah semua bentuk perilaku yang tidak sesuai dengan nilai dan norma sosial yang berlaku di masyarakat (Herabudin, 2015, p. 252). Bentuk dan macam-macam perilaku menyimpang remaja adalah:

a) Tawuran pelajar

b) Penyimpangan seksual meliputi homoseksual, lesbianisme, dan hubungan seksual sebelum menikah. c) Alkoholisme.

d) Penyalahgunaan obat terlarang atau narkotika.

e) Kebut-kebutan di jalan raya.

f) Pencurian atau penipuan dan sebagainya.

3) Masalah Lingkungan Hidup

Masalah lingkungan hidup dapat berupa berubahnya suatu kondisi lingkungan yang dapat menyebabkan pencemaran lingkungan dan lingkungan tersebut kurang layak.

4) Masalah Konflik SARA

Masalah konflik suku, agama, ras, dan antar kelompok (SARA), bagi negara-negara berkembang yang multikultural adalah problem yang dapat mengganggu kelancaran proses pembangunan. Karena setiap desain pembangunan dan pelaksanaan pembangunan harus betul-betul meminimalkan terjadinya konflik SARA. Unsur-unsur konflik SARA adalah:

a) Dua pihak atau lebih yang terlibat konflik

b) Tujuan yang menjadi sasaran konflik, dan tujuan tersebut sebagai sumber konflik

c) Perbedaan pikiran, perasaan, dan tindakan untuk meraih tujuan yang saling memaksakan atau menghancurkan.

5) Masalah Kriminalitas

Krimnalitas atau tindakan kriminal merupakan masalah sosial yang bersifat laten (selalu ada dalam kehidupan masyarakat atau negara manapun). Tindak kriminal bukan hanya penyimpangan perilaku yang dibawa sejak lahir, melaikan merupakan hasil sosialisasi subbudaya yang menyimpang.

6) Masalah Aksi Protes, Pergolakan Daerah dan Pelanggaran HAM

Aksi protes, pergolakan daerah, dan pelanggaran HAM merupakan masalah sosial yang cukup kompleks. Karena Indonesia merupakan salah satu contoh negara yang memiliki kondisi sosial budaya masyarakat yang multikultural. Sehinga menyebabkan hampir setiap hari banyak aksi protes dan demonstrasi di daerah- daerah. Hal tersebut dapat mengganggu proses perubahan atau pembangunan masyarakat.

Selain itu, menurut Soekanto (2007, p. 312) jenisjenis masalah sosial dapat dikategorikan pada kategori tertentu berdasarkan faktor-faktor penyebabnya, yaitu:

\section{1) Faktor Ekonomi}

Ekonomi merupakan faktor yang paling penting dalam kehidupan sosial. Isu sosial yang terjadi di masyarakat saat ini banyak disebabkan dari faktor ekonomi, karena banyak isu sosial yang timbul akibat kemiskinan maupun pengangguran. Faktor 
ekonomi juga menjadi tolak ukur kemajuan dalam sebuah negara yang memiliki pengaruh sangat besar. Selain itu rendahnya ekonomi masyarakat juga dapat menyebabkan rendahnya rata-rata tingkat pendidikan sehingga akan dapat menimbulkan masalah-masalah sosial lainnya di sekitar masyarakat.

2) Faktor Biologis

Faktor biologis dapat timbul karena adanya wabah penyakit maupun bencana alam. Hal tersebut dapat menimbulkan kurangnya fasilitas kesehatan dan kondisi ekonomi yang tidak menunjang. Selain itu kurangnya fasilitas kesehatan dan kebersihan yang ada dapat menyebabkan munculnya penyakit yang menular di suatu wilayah.

3) Faktor Biopsikologis

Isu sosial juga muncul dari faktor biopsikologis, dimana faktor biopsikologis merupakan masalah sosial yang terjadi akibat dari faktor yang berhubungan dengan pola pikir masyarakat yang terkait. Pola pikir tersebut dipengaruhi oleh nilainilai yang ditanamkan, sejarah masyarakat, lingkungan pergaulan, tingkat pendidikan, tingkat ekonomi, dan sebagainya.

4) Faktor Kebudayaan

Dalam faktor kebudayaan, masalah sosial dapat terjadi akibat adanya perbedaan nilai-nilai yang dianut satu orang dengan yang lainnya atau adanya perubahan nilai di masyarakat. isu sosial dapat timbul karena masalah-masalah seperti kenakalan remaja, pernikahan di usia dini, hamil di luar nikah, dan sebagainya. Hal tersebut apabila dibiarkan, akan menjadi sebuah kebiasan yang negatif.

\subsection{Komunitas Meme di Instagram}

Meme merupakan sebuah duplikasi ide yang di hasilkan dari sebuah kelompok atau biasa disebut dengan komunitas. Komunitas sendiri merupakan sekumpulan orang yang mempunyai kepentingan bersama. Dengan demikian, terdapat komunitas pecinta atau penyuka meme yang tersebar luas di instagram. Komunitas meme yang terkenal di instagram salah satunya adalah akun @memecomic.id. Akun @memecomic.id adalah salah satu akun komunitas meme yang berasal dari Indonesia yang didirikan pada tahun 2012. Pada awalnya komunitas meme ini berawal dari sebuah fanpage facebook, kemudian berkembang ke media twitter, setelah itu membuat situs web, dan pada akhirnya mengembangkan juga komunitasnya di media sosial instagram. Dari semua media sosial yang dimiliki oleh @memecomic.id semua akun dan situs web mereka masih aktif untuk memposting sesuatu hingga saat ini. keseharian para admin MCI dan upaya-upaya yang dilakukan untuk mengembangkan komunitas MCI tersebut (Arifianti, 2015).

Karakteristik meme yang diunggah pada instagram MCI adalah, mereka banyak mem-posting tentang meme yang berkaitan dengan humor, kritik-kritik megenai suatu kejadian, maupun screenshoot beritaberita yang viral kemudian diunggah kembali oleh akun tersebut lalu setelah itu di berikan komentar oleh followers-followers MCI tersebut. Konten-konten isu yang diunggah pada MCI pun beragam, mulai dari isu politik, isu remaja, maupun isu sosial. Namun, dari daftar unggahan yang di posting di instagram MCI, konten isu sosial lah yang paling banyak di singgung dan banyak di jadikan meme. Dengan demikian, dapat dikatakan bahwa isu sosial dianggap penting bagi akun MCI untuk diperbincangkan maupun dijadikan meme oleh komunitas meme online MCI.

\section{HASIL PENELITIAN}

Menjelang pemilihan presiden 2019 ada beberapa isu yang banyak diperbincangkan oleh masyarakat. Salah satu isu yang menjadi dominasi menjelang pemilihan presiden 2019 adalah isu politik. Di samping perbincangan isu politik yang mendominasi menjelang pilpres 2019, terdapat isu-isu yang terpinggirkan oleh masyarakat namun masih dianggap penting atau populer. Salah satu isu yang populer menjelang pemilihan presiden 2019 selain isu politik adalah isu sosial. Isu sosial dapat dianggap penting oleh masyarakat menjelang pemilihan presiden 2019 karena masih banyak masyarakat yang memperbincangkan isu sosial dalam bentuk meme. Seperti yang dikatakan oleh Richard Dawkins (2006), "At any given moment, many memes are competing for the attention of hosts; however, only memes suited to their sociocultural environment spread successfully, while others become extinct". Maksud dari kalimat yang diungkapkan oleh Richard Dawkins adalah banyak meme yang berkompetisi untuk mendapatkan perhatian, namun hanya meme yang sesuai dengan sosial budaya masyarakat saja yang akan bertahan, sementara meme yang lainnya akan punah. Dengan demikian isu sosial masih populer dan dianggap penting oleh masyarakat di dalam lingkaran isu politik yang mendominasi karena isu sosial memiliki implikasi dengan isu politik menjelang pemilihan presiden 2019 yang disebarluaskan dalam bentuk meme ke berbagai media. Pada pembahasan ini, peneliti akan menggambarkan secara umum isi konten dari isu sosial yang direplikasi menjadi sebuah meme yang telah dibahas sebelumnya pada hasil penelitian. 
Dari hasil penelitian yang sudah dilakukan, peneliti menemukan bahwa terdapat enam meme isu sosial menjelang pemilihan presiden 2019 yang diperbincangkan melalui 2 kategorisasi, yaitu kategorisasi yang pertama adalah isu sosial dibuat meme dengan bentuk sindiran secara serius, artinya adalah isu sosial diperbincangkan hanya dalam bentuk sindiran saja. Kemudian kategorisasi yang kedua adalah isu sosial diperbincangkan melalui meme gambar dengan tidak serius atau menggunakan unsur humor dan lelucon. Kategori isu sosial yang pertama adalah isu sosial yang diperbincangkan secara serius atau tidak menggunakan unsur humor. Terdapat dua meme yang diperbincangkan dengan berupa sindiran serius atau tidak menggunakan unsur lelucon. meme-meme tersebut yaitu:

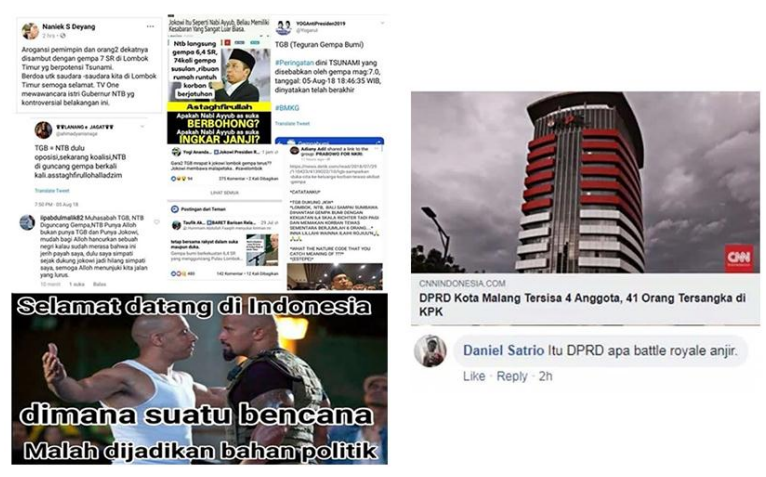

Gambar 1. Meme Sindiran Serius

Kedua meme tersebut merupakan meme yang membahas mengenai masalah isu SARA dan masalah korupsi yang terjadi di Indonesia. Isu SARA dikatakan merupakan isu yang menjadi ancaman terbesar menjelang pilpres 2019 (Jegho, 2018). Meme isu SARA tersebut merupakan meme yang terjadi karena peristiwa bencana alam di Lombok yang dikaitkaitkan dengan agama yang menjadi bahan perbincangan politik. Pada gambar tersebut pembuat dan penyebar meme ingin menunjukkan komentarkomentar yang disampaikan oleh netizen mengenai penyebab kejadian bencana alam yang terjadi di Lombok, komentar-komentar yang disampaikan dapat dikatakan menyinggung isu SARA tepatnya isu agama. Kemudian pada meme kedua merupakan meme yang membahas mengenai masalah korupsi yang terjadi pada DPRD kota Malang. Meme-meme tersebut dapat dikatakan sebagai meme bentuk sindiran yang serius karena kedua meme tersebut merupakan meme yang dibuat berdasarkan peristiwaperistiwa yang pernah terjadi di Indonesia. Namun pembuat dan penyebar meme memperbincangkan masalah atau isu sosial tersebut dengan tidak menggunakan unsur humor atau lelucon. Sehingga meme tersebut hanya berbentuk murni sindiran bagi pembuat dan penyebar meme itu sendiri terhadap peristiwa-peristiwa yang terjadi pada meme tersebut.

Kategorisasi yang kedua adalah isu sosial yang diperbincangkan melalui meme gambar yang menggunakan lelucon atau unsur humor dalam menyampaikan pendapat maupun kritik mengenai suatu kejadian. Terdapat beberapa meme yang dibuat dan disebarkan yang termasuk kedalam meme leleucon isu sosial. Meme-meme tersebut adalah:

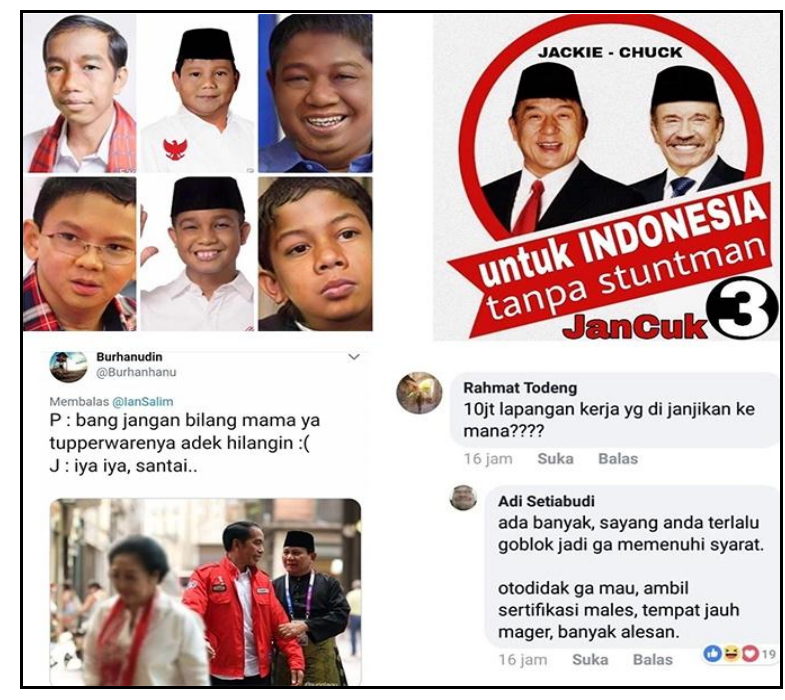

Gambar 2. Meme Sindiran dengan Lelucon

Terdapat empat meme yang membahas mengenai isu sosial yang terjadi di Indonesia yang direplikasi menjadi meme gambar yang menggunakan unsur humor atau lelucon. Pada gambar pertama merupakan meme hasil gabungan dari foto-foto tokoh-tokoh politik di Indonesia yang digabungkan dengan foto anak kecil. Kemudian pada gambar kedua merupakan masalah sosial yang terjadi ketika presiden Jokowi menggunakan stuntman pada acara penutupan Asian Games 2018, peristiwa tersebut dikatakan sebagai bentuk pencitraan presiden Jokowi untuk menarik kaum millennial untuk mendukung Jokowi pada pemilu 2019. Kemudian pada gambar ketiga merupakan meme isu sosial yang tidak serius, dimana masalah yang diperbincangkan adalah masalah yang sering terjadi di kalangan remaja anak-anak yang takut apabila menghilangkan tupperware, masalah sosial tersebut kemudian digabungkan dengan foto Jokowi, Prabowo dan Megawati sebagai bentuk penggambaran menjelang pilpres 2019. Dan pada gambar terakhir merupakan meme mengenai sindiran masyarakat mengenai janji presiden Jokowi dengan memberikan 10 juta lapangan pekerjaan bagi masyarakat Indonesia. Bentuk sindiran tersebut dibalas dengan komentar netizen yang lucu dengan mengolok-olokan sindiran netizen tersebut. 


\section{PEMBAHASAN}

Jika dilihat dari keenam meme yang diunggah oleh akun instagram MCI menjelang pemilihan presiden 2019, sikap atau stance seseorang yang membuat dan menyebarkan meme tersebut adalah seseorang yang kontra atau tidak setuju dengan tindakan atau peristiwa-peristiwa isu sosial yang ada di Indonesia saat ini. Bentuk ketidaksetujuannya diluapkan dengan menggunakan meme gambar. Dengan menggunakan meme gambar, pembuat dan penyebar dapat meluapkan pendapatnya mengenai isu sosial tersebut secara tidak terang-terangan atau tidak frontal. Pembuat dan penyebar meme tersebut ingin memberikan sindiran maupun menyinggung berbagai peristiwa yang terjadi menjelang pemilihan presiden 2019 dengan meme gambar yang diunggah oleh instagram MCI tersebut secara tidak frontal, sehingga pembuat dan penyebar dapat memberikan pendapatnya mengenai ketidaksetujuan dan kegeraman masyarakat mengenai isu-isu sosial yang terjadi di Indonesia yang diungkapkan dengan melakukan sindiran dengan menggunakan meme gambar. Seperti yang dikatakan oleh Alfiansyah (2016, p. 162), di Indonesia meme yang hadir tak jarang berisi komentar dan sindiran terhadap situai sosial dan politik yang terjadi.

Melihat sikap atau stance dari pembuat dan penyebar meme yang telah dijelaskan sebelumnya, dapat terlihat bahwa meme-meme yang diunggah oleh instagram MCI merupakan meme yang berbentuk gambar yang sebagian besar meme tersebut terdiri dari beberapa cerita yang dapat menjadi sebuah kesatuan cerita. Kemudian cerita atau konten dari meme tersebut dikemas oleh pembuat dan penyebar meme menjadi sebuah sindiran terhadap suatu peristiwa menjelang pemilihan presiden 2019 yang sedang terjadi secara serius dan menggunakan unsur humor atau lelucon di dalam sindiran meme tersebut. Menurut Ika (2018), sindiran yang dibungkus dalam humor cenderung lebih bisa diterima dan tidak membuat marah objek yang disindir. Dengan demikian, saat ini banyak meme yang beredar dalam bentuk sindiran yang menggunakan unsur humor atau lelucon, hal tersebut dikarenakan agar tidak terlalu serius dan dapat lebih mudah diterima.

Saat ini pemerintah dapat mengetahui permasalahanpermasalahan dan sindiran-sindiran untuk pemerintah di Indonesia dengan melihat meme-meme yang tersebar di berbagai media. Hal tersebut dikarenakan saat ini meme merupakan salah satu sarana penyampaian pesan, ekspresi, dan perasaan bagi seorang yang membuat dan menyebarkan meme tersebut. Tidak semua meme mengandung isi pesan dengan per- masalahan serius, melainkan saat ini kebanyakan meme yang mengandung suatu pesan yang diselipkan dengan konten humor. Dengan demikian masyarakat dapat lebih mudah dalam menyampaikan pesan dan perasaan maupun dalam mencerna isi pesan yang terdapat pada suatu meme. Seperti pada meme-meme yang diunggah pada instagram MCI menjelang pemilihan presiden 2019, akun MCI mencoba untuk menyebarkan meme-meme yang berkaitan dengan isu sosial menjelang pemilihan presiden 2019 yaitu pada bulan Agustus-November 2019 dengan menyampaikan permasalahan-permasalahan sosial yang terjadi di Indonesia dengan konten yang serius maupun tidak serius dimana isu sosial tersebut dibuat menjadi sebuah meme gambar yang diselipkan dengan lelucon/humor. Sehingga masyarakat yang melihat dan ikut menyebarkan meme tersebut dapat lebih mudah dalam mencerna maksud dari konten yang disampaikan oleh pembuat meme. Meskipun terkadang banyak meme-meme yang mengandung humor yang bersifat sarcastic atau mengolokolokkan.

Terdapat enam jenis isu sosial yang dikemukakan oleh Herabudin (2015), yaitu isu sosial kemiskinan, kenakalan remaja, masalah lingkungan hidup, masalah konflik SARA, masalah kriminalitas, dan masalah pelanggaran HAM, namun menjelang pemilihan presiden 2019, akun instagram @memecomic.id hanya menyinggung isu sosial yang dikemukakan oleh Herabudin mengenai masalah isu SARA dan kriminalitas dengan tindakan korupsi. Masalah sosial lainnya yang diperbincangkan menjelang pemilihan presiden 2019 oleh akun @memecomic.id adalah masalah sosial yang berkaitan dengan masalah sosial menurut Soekanto (2007) yaitu jenis isu sosial yang disebabkan oleh faktor ekonomi, dan biopsikologis. Dimana dimana masalah sosial yang disebabkan oleh faktor ekonomi diperbincangkan melalui meme dengan permasalahan kurangnya lapangan pekerjaan. Selain itu masalah sosial yang diperbincangkan juga masalah sosial akbat dari faktor biopsikologis, yaitu pandangan masyarakat mengenai suatu peristiwa dari nilai-nilai yang sudah tertanam dari masyarakat sebelumnya, masalah sosial tersebut diperbincangkan menggunakan meme mengenai penggunaan stuntman yang dilakukan oleh presiden Jokowi dipandang merupakan hal yang dianggap sebagai tindak pencitraan, kemudian masalah sosial yang tidak serius yaitu masalah kehilangan tupperware yang dikaitkan dengan masalah Jokowi, Prabowo, dan Megawati. Selanjutnya adalah masalah sosial yang menganggap tokoh-tokoh politik di Indonesia masih memiliki sifat dan perilaku seperti anak kecil. 
Dengan demikian dapat dikatakan bahwa walaupun isu politik merupakan isu yang mendominasi menjelang pemilihan presiden 2019, masih banyak terdapat isu-isu lain yang terpinggirkan namun dianggap populer dan penting oleh masyarakat. Salah satu isu yang dianggap populer menjelang pemilihan presiden 2019 yaitu isu sosial yang memiliki implikasi dengan isu politik. Hal tersebut dikarenakan menjelang pemilihan presiden 2019, isu-isu sosial tersebut masih diperbincangkan oleh masyarakat dalam bentuk meme, dimana meme sendiri dapat bertahan apabila terdapat suatu kejadian atau isu-isu yang dianggap populer dan sesuai dengan sosial dan budaya masyarakat. Pada hasil penelitian ini, peneliti menemukan terdapat enam meme yang berkaitan dengan isu sosial yang memiliki implikasi dengan isu politik yang diperbincangkan menjelang pemilihan presiden 2019 yang diunggah oleh instagram @memecomic.id. Karena itu, menjelang pemilihan presiden 2019 isu sosial merupakan salah satu isu yang dianggap populer dan penting yang memiliki implikasi dengan isu politik.

\section{KESIMPULAN}

Setelah melakukan analisis dari data meme gambar yang diperoleh dari instagram @ memecomic.id menjelang pemilihan presiden 2019 yaitu pada bulan Agustus - November 2018, peneliti dapat membuat kesimpulan yang sesuai dengan permasalahan dan tujuan penelitian. Adapun hasil simpulan yang didapat oleh peneliti yaitu menjelang pemilihan presiden 2019 peneliti menemukan terdapat beberapa jenis isu sosial yang diperbincangkan menggunakan meme gambar. Pertama adalah isu sosial mengenai masalah SARA yang mengkaitkan isu politik dengan agama, kemudian isu sosial mengenai masalah kriminalitas yang dibahas mengenai tindakan korupsi. Selain itu terdapat masalah sosial yang terjadi akibat dari faktor ekonomi yang menimbulkan kurangnya lapangan pekerjaan. Selanjutnya adalah isu sosial yang timbul akibat dari faktor biopsikologis yang diperbincangkan mengenai masalah-masalah yang berhubungan dengan perbedaan pola pikir masyarakat mengenai suatu peristiwa atau kejadian.

Selain itu, Meme isu sosial yang diunggah pada akun instagram @memecomic.id merupakan meme yang berkaitan dengan sebagian dari masalah-masalah sosial menjelang pemilihan presiden 2019 yang dikemukakan oleh Herabudin dan Soekanto. Meme tersebut dibuat berdasarkan hasil penyampaian pendapat atau sebuah kritik yang dituangkan menjadi sebuah meme gambar yang berbentuk sindiran atau menyinggung secara tidak frontal. Isi konten yang terdapat pada setiap meme pun berbeda-beda, kontenkonten tersebut dijadikan meme gambar yang dibuat secara serius atau tidak menggunakan lelucon dan meme berbentuk sindiran secara tidak serius, atinya meme-meme tersebut dibuat dengan menambahkan unsur humor atau lelucon. Sehingga penyampaian pendapat mengenai isu-isu sosial yang sedang terjadi di Indonesia menjelang pemilihan presiden 2019 dapat disampaikan dengan menggunakan meme gambar yang sifatnya tidak terang-terangan atau frontal dengan konten yang serius maupun tidak serius

\section{DAFTAR PUSTAKA}

Aliansyah, M. A. (2017). Penyebar Meme Penghina Jokowi divonis 15 Bulan Penjara. Retrieved December 22, 2018, from https://www.merdeka. com/peristiwa/penyebar-meme-penghina-jokowidivonis-15-bulan-penjara.html

Allifiansyah, S. (2016). Kaum Muda, Meme, dan Demokrasi Digital di Indonesia. Jurnal Ilmu Komunikasi, 13(2), 151-164.

Arifianti, W. (2015). If You Know What Happened in MCI. (M. K. Julianto, Ed.). Jakarta: Penerbit Loveable.

Asmoro, G. (2018). Keeping an Eye on 2019 Presidential Election. Retrieved November 28, 2018, from http://www.globalindonesianvoices. com/33271/keeping-an-eye-on-2019-presidential-election/

Campbell, H. A., Arredondo, K., Dundas, K., \& Wolf, C. (2018). The Dissonance of "Civil" Religion in Religious-Political Memetic Discourse During the 2016 Presidential Elections. Social Media and Society, 4(2). http://doi.org/ 10.1177/2056305118782678

Dawkins, Ri. (2006). The Selfish Gene (30th anner). New York: Oxford University Press.

Dewi, R. S., Abdullah, A., Maryani, E., \& Suganda, D. (2017). Internet Memes: Representation of Indonesian Political Culture in Jakarta Gubernatorial Election 2017. AEBMR International Conference on Administrative Science (ICAS 2017), 43(Icas), 190-194. http://doi.org/doi: 10.2991/icas-17.2017.45

Faisal, R. (2018). Pembuat Meme Menghina Presiden Ditangkap Polisi. Retrieved March 22, 2018, from https://www.jawapos.com/radarbromo/ read/2018/01/20/41971/terungkap-nekat-hinapresiden-di-facebook-karena-muatan-politis. 
Firmansyah. (2018). Polisi Tangkap Pegawai negeri Penyebar Meme Jokowi Layaknya Pengemis. Retrieved November 28, 2018, from http://suryamalang.tribunnews.com/2018/06/09/polisitangkap-pegawai-negeri-penyebar-memejokowi-layaknya-pengemis?page $=1$

Halim, D. (2018). Daftar Penyebar Hoax Jokowi yang Ditangkap Polisi, Ada yang Bikin 843 Meme Hoax. Retrieved November 28, 2018, from http:/jambi.tribunnews.com/2018/11/26/ daftar-penyebar-hoax-jokowi-yang-ditangkappolisi-ada-yang-bikin-843-meme-hoax

Harahap. (2018). Evaluasi Kritis terhadap Kinerja Presiden Jokowi Urusi Masalah Sosial. Retrieved from https://nusantaranews.co/evaluasikritis-terhadap-kinerja-presiden-jokowi-urusimasalah-sosial/

Herabudin. (2015). Pengantar Sosiologi. Bandung: CV Pustaka Setia.

Ika, B. (2018). Sindiran dalam Meme Humor terhadap Presiden SBY (Studi Analisis Semiotika Sindiran sebagai Kritik Sosial yang dipresentasikan dalam Meme versi Kenaikan Harga BBM di Media Sosial). Universitas Sebelas Maret.
Jegho, L. (2018). Mengawasi Pemilu Presiden 2019 dan Melihat Sejarah Demokrasi Indonesia. Retrieved from https://www.matamatapolitik. com/mengawasi-pemilu-presiden-2019-danmelihat-sejarah-demokrasi-indonesia/

Juditha, C. (2015). Meme di Media Sosial: Analisis Semiotik Meme Haji Lulung. Jurnal Pekomnas, 18 (2)(2), 105-116. Retrieved from https://jurnal. kominfo.go.id/index.php/pekommas/article/view /301

Nurgiyantoro, B. (2005). Sastra Anak, Pengantar Pemahaman Dunia Anak. Yogyakarta: Gadjah Mada Univerisy Press.

Seiffert-Brockmann, J., Diehl, T., \& Dobusch, L. (2018). Memes as games: The evolution of a digital discourse online. New Media and Society, 2O(8), 2862-2879. http://doi.org/10.1177/1461 444817735334

Shifman, L. (2014). Memes in Digital Culture. Massachusetts: MIT Press.

Silvestri, L. (2016). Mortars and memes: Participating in pop culture from a war zone. Media, War \& Concflict, 9(1), 27-42. http://doi.org/ $10.1177 / 1750635215611608$

Soekanto, S. (2007). Sosiologi Suatu Pengantar. Jakarta: PT Raja Grafindo. 